\title{
DAYA HAMBAT EKSTRAK ETANOL DAUN SURUHAN (Peperomia pellucida L.) TERHADAP PERTUMBUHAN BAKTERI PENYEBAB JERAWAT (Propionibacterium acnes) DENGAN METODE SUMUR AGAR
}

\author{
Fadly Putrajaya, Nur Hasanah, Anis Kurlya \\ Sekolah Tinggi Ilmu Kesehatan Kharisma Persada \\ Tangerang Selatan, 15417, Indonesia \\ E-mail: fadly.putrajaya@masda.ac.id
}

\begin{abstract}
ABSTRAK
Jerawat atau acne vulgaris adalah penyakit kulit obstruktif dan inflamatif kronik pada pilosebasea yang sering terjadi di kalangan remaja. Menurut catatan studi dermatologi kosmetika Indonesia, penderita acne vulgaris pada tahun 2006, 2007, dan 2009 berturut-turut sebanyak 60, 80, dan 90\%. Prevalensi tertinggi pada wanita (14-17 tahun) berkisar 83-85\% dan pada pria (16-19 tahun) berkisar 95-100\%. Oleh karena itu, perlu adanya alternatif lain untuk meminimalisir terjadinya resistensi antibiotik dan mencegah terjadinya efek samping. Salah satu alternatifnya yaitu dengan menggunakan antibakteri yang berasal dari bahan alam. Salah satu bahan alam yang dapat dimanfaatkan adalah daun suruhan (Peperomia pellucida L.). Penelitian ini bertujuan untuk mengetahui daya hambat ekstrak etanol daun suruhan terhadap pertumbuhan bakteri penyebab jerawat (Propionibacterium acnes). Penelitian ini merupakan penelitian eksperimental. Data yang digunakan dalam penelitian ini adalah diameter zona bening. Hasil penelitian menunjukkan ekstrak etanol daun suruhan (Peperomia pellucida L.) memiliki kemampuan hambat terhadap bakteri penyebab jerawat (Propionibacterium acnes) pada konsentrasi $25 \%(6,65 \mathrm{~mm}),\left(129,39 \mathrm{~mm}^{2}\right)$ maka daya hambat tergolong sedang, konsentrasi $50 \%(8,2 \mathrm{~mm}),\left(130,98 \mathrm{~mm}^{2}\right)$ maka daya hambat tergolong sedang, konsentrasi $75 \%(13,7$ $\mathrm{mm}),\left(532,42 \mathrm{~mm}^{2}\right)$ maka daya hambat tergolong kuat, konsentrasi $100 \%(17,15 \mathrm{~mm}),\left(539,1 \mathrm{~mm}^{2}\right) \mathrm{maka}^{2}$ daya hambat tergolong kuat. Disarankan penelitian selanjutnya, perlu dilakukan fraksinasi ekstrak etanol daun suruhan untuk mengetahui senyawa aktif yang berperan sebagai antibakteri dengan menggunakan pelarut polar dan pelarut non polar.
\end{abstract}

Kata kunci : Daya Hambat, Daun Suruhan (Peperomia pellucida L.), Propionibacterium acnes, Metode Sumur Agar

\begin{abstract}
Pimples or acne vulgaris are obstructive skin diseases and chronic inflamatif in pilosebaseas that often occur among adolescents. According to the Indonesian Cosmetic Dermatology Study, sufferers of acne vulgaris in 2006, 2007 and 2009 in a row as much as 60, 80, and 90\%. The highest prevalence in women (1417 years) ranges from $83-85 \%$ and in men (16-19 years) ranged from 95-100\%. Therefore, there is a need for altervatives to minimize antibiotic resistance and prevent side effects from occurring. One alternative is the use of antibacterial that comes from natural ingredients. One of the natural ingredients that can be utilized is suruhan leaf (Peperomia pellucida L.). The study aims to find out the power of ethanol extract of the suruhan leaf against the growth of acne causing bacteria (Propionibacterium acnes). This research is an experimental study. The data used in this study is the diameter of the clear zone. The results of the study showed the ethanol extract of the suruhan leaf (Peperomia pellucida L.) has a barrier to acne causing bacteria (Propionibacterium acnes). At a concentration $25 \%(6,65 \mathrm{~mm}),\left(129,39 \mathrm{~mm}^{2}\right)$ then the resistance is medium, the concertration of $50 \%(8,2 \mathrm{~mm}),\left(130,98 \mathrm{~mm}^{2}\right)$ then the resistance is relatively medium, concentration $75 \%$ $(13,7 \mathrm{~mm}),\left(532,42 \mathrm{~mm}^{2}\right)$ then the resistance is relatively strong, the concentration of $100 \%(17,15 \mathrm{~mm})$, $\left(539,1 \mathrm{~mm}^{2}\right)$ then the power is relatively strong. Further research is suggested, fractionation extract of suruhan leaf ethanol to know the active compounds that act as antibacterial using polar solvents and non polar solvents.
\end{abstract}

Keywords : : Power Barrier, Suruhan Leaf(Peperomia pellucida L.), Propionibacterium acnes, Well Method 


\section{PENDAHULUAN}

Jerawat atau Acne vulgaris adalah penyakit kulit obstruktif dan inflamatif kronik pada pilosebasea yang sering terjadi di kalangan remaja (Movita, 2013). Menurut catatan studi dermatologi kosmetika Indonesia, penderita Acne vulgaris pada tahun 2006, 2007, dan 2009 berturut-turut sebanyak 60, 80, dan $90 \%$. Prevelansi tertinggi pada wanita (14-17 tahun) berkisar 83-85\% dan pada pria (1619 tahun) berkisar 95-100\% (Afriyanti, 2015).

Pengobatan jerawat dapat menggunakan obat dari golongan antibiotik. Namun pengobatan dengan antibiotik dapat menyebabkan kerugian seperti terjadinya efek samping, dapat menyebabkan resistensi bakteri dan juga harganya yang mahal (Febriyati, 2010). Oleh karena itu, perlu adanya alternatif lain untuk meminimalisir terjadinya resistensi antibiotik dan mencegah terjadinya efek samping. Salah satu bahan alam yang dapat dimanfaatkan sebagai antibakteri adalah daun suruhan (Peperomia pellucida L.). Daun suruhan secara lokal di daerah Sleman Yogyakarta dikenal sebagai suruhan sedangkan di daerah Gowa Sulawesi Selatan di kenal sebagai daun kaca-kaca, tanaman ini sering digunakan sebagai ramuan dalam pengobatan tradisional.

Daun suruhan secara luas sudah tersebar luas di banyak negara, seperti Amerika dan Asia Selatan (ArrigoniBlank dalam Dyan, 2014). Tumbuhan suruhan ini sudah lama dikenal oleh masyarakat luas yang dapat digunakan sebagai obat, bahkan telah diperdagangkan dengan nama dagang suruhan. Secara empiris, herba suruhan dapat mengobati sakit kepala, nyeri perut, dan membantu mengatasi timbulnya jerawat. Suruhan umumnya dikonsumsi dengan cara diseduh, tetapi ada juga yang mengkonsumsinya sebagai lalapan segar (Cao, 2011).

Pengujian secara ilmiah mengenai khasiat daun suruhan (Peperomia pellucida L.) yang diekstraksi dengan menggunakan etanol sebagai antibakteri sejauh ini belum pernah dilaporkan. Untuk membuktikan secara ilmiah maka dilakukan pengujian antibakteri pada bakteri Propionibacterium acnes. Tujuan penelitian ini yaitu mengidentifikasi parameter standar mutu ekstrak berdasarkan parameter spesifik (determinasi tanaman, organoleptis ekstrak dan skrining fitokimia) dan parameter non spesifik (uji kadar abu). Mengidentifikasi daya hambat ekstrak 124 
etanol daun suruhan dengan variasi konsentrasi 25\%, 50\%, 75\%, dan 100\% terhadap bakteri penyebab jerawat (Propionibacterium acnes) dengan metode sumur agar.

\section{METODE}

Penelitian ini dilaksanakan pada bulan Maret-Juni 2019. Alat yang digunakan dalam penelitian ini antara lain : oven (Memmert), LAF (Laminar Air Flow) (ABL-LAF100), autoklaf (GEA Model YX-18LM), colony counter (Pupick Med), water bath (WB-1L4H), hot plate (NESCO LAB), ayakan (MESH), timbangan analitik (UWE), gaspak (AnaeroGen $^{\mathrm{TM}} \quad$ Compact), batang pengaduk, batang L, cawan petri, erlenmeyer, gelas ukur, jarum ose, tips, pipet mikro, jangka sorong, kertas perkamen, spatel, tali, kertas, kapas gulung, tabung reaksi, plastic wrap, sarung tangan, dan masker.

Bahan kimia yang digunakan dalam penelitian ini antara lain : etanol 96\%, nutrient agar (NA), nutrient broth (NB), spiritus, dan larutan $\mathrm{NaCl}$ 0,9\%.

Bahan uji yang digunakan dalam penelitian ini antara lain : aquadest, clindamycin $150 \mathrm{mg}$, kapsul komersil, ekstrak etanol daun suruhan dengan variasi konsentrasi $25 \%, 50 \%, 75 \%$ dan $100 \%$.
Hewan uji yang digunakan dalam penelitian ini yaitu bakteri Propionibacterium acnes.

\section{Pembuatan Ekstrak Etanol Daun}

\section{Suruhan}

Daun suruhan yang sudah diambil, dicuci bersih, kemudian dijemur sampai kering. Daun suruhan yang didapat $\pm 2 \mathrm{~kg}$. Setelah daun menjadi kering, kemudian di haluskan hingga menjadi serbuk simplisia. Serbuk yang sudah dihaluskan kemudian diayak dengan ayakan nomor 12, 14, 16, 18 dan 20. Serbuk simplisia ditimbang dan didapat \pm 300 gram simplisia, kemudian dilakukan maserasi menggunakan etanol $96 \%$ dengan perbandingan 1:10. Dilakukan selama $3 \mathrm{x}$ 24 jam. Kemudian, disaring. Filtrat yang didapat kemudian di evaporasi dalam suhu $60^{\circ} \mathrm{C}$ sampai didapatkan ekstrak kental dari daun suruhan. Ekstrak yang didapat \pm 25 gram. Untuk menetapkan rendemen ekstrak, sejumlah tertentu ekstrak kental dalam cawan penguap ditimbang kemudian di atas penangas air dengan temperatur $40-50^{\circ} \mathrm{C}$ sampai bobot tetap. Tentukan berat ekstrak setelah penguapan dengan mengurangkan dengan bobot cawan kosong. Kemudian dihitung rendemen ekstrak $(\% \mathrm{~b} / \mathrm{b})$ sesuai dengan rumus : 
Fendemen $(\varphi)=$ berat ekstrak total berat simplisia

\section{Standarisasi Ekstrak}

\section{Determinasi Tanaman}

Determinasi merupakan suatu kegiatan karakteristik yang dimiliki oleh sumber keragaman genetik tanaman. Determinasi dilakukan untuk mencari dan mengenal ciri-ciri taksonomi individu yang beranekaragaman, determinasi berdasarkan karakter morfologi sangat berguna untuk mengetahui berbagai jenis dan keragaman varietas (Mayr dkk., 1991 dalam Saraswati, 2015).

\section{Organoleptis Ekstrak}

Ekstrak yang telah diperoleh, kemudian diidentifikasi secara organoleptis. Pemeriksaan organoleptis meliputi bentuk, warna, bau, dan rasa (Permawati, 2008 dalam Saraswati, 2015).

\section{Skrining Fitokimia}

\section{Alkaloid}

Metode : Ekstrak di tetesi dengan larutan $\mathrm{HCl} 2 \mathrm{~N}$ kemudian dikocok. Sampel dibagi menjadi 3 tabung dan diperlakukan sebagai berikut :

Tabung 1 ditetesi dengan larutan pereaksi Mayer, kemudian diamati ada atau tidaknya endapan berwarna putih. $x$ Thaggng 2 ditetesi dengan larutan pereaksi Dragendroff, kemudian diamati ada atau tidaknya endapan jingga.

Tabung 3 digunakan sebagai blanko (Tiwari dkk., 2011).

\section{Flavonoid}

Metode : Ekstrak ditambahkan 10 $\mathrm{mL}$ air panas kemudian didinginkan dan disaring. Filtrat diambil dan ditambahkan serbuk magnesium. Kemudian ditetesi larutan $\mathrm{HCl}$ pekat dan amil alkohol. Lalu kocok kuat sampai memisah. Kemudian diamati larutan menjadi berwarna orange, merah/kuning atau tidak (Tiwari dkk., 2011).

\section{Saponin}

Metode : Ekstrak ditambahkan 10 $\mathrm{mL}$ air panas kemudian didinginkan dan dikocok kuat selama 10 detik. Kemudian diamati ada atau tidaknya busa setinggi 1 cm dan busa akan stabil apabila ditetesi larutan $\mathrm{HCl}$ (Tiwari dkk., 2011).

Fenolik dan Tanin

Metode : Ekstrak ditambahkan 3 $\mathrm{mL}$ air hangat. Ekstrak diujikan dengan 12 tetes $\mathrm{FeCl}_{3} 1 \%$ terbentuk warna biru tua atau hijau kehitaman menunjukkan adanya senyawa golongan fenol dan tanin (Markham, 1988 dalam Saraswati, 2015). Steroid dan Triterpenoid

Metode : Ekstrak ditambahkan 1 $\mathrm{mL} \mathrm{H} 2 \mathrm{SO} 4$ pekat dan $1 \mathrm{~mL}$ asam asetat. 
Hasil positif bila terbentuknya cincin kecokletan atau violet menunjukkan adanya triterpenoid. Hasil positif bila terbentuknya warna biru kehijauan menunjukkan adanya golongan steroid (Subagja, 2017).

\section{Glikosida}

Metode : Ekstrak dilarutkan dalam pelarut etanol, diuapkan di atas penangas air lalu dilarutkan dalam $5 \mathrm{~mL}$ asam asetat anhidrida kemudian ditambah 10 tetes asam sulfat pekat. Terbentuknya warna biru atau hijau menunjukkan adanya glikosida (Depkes RI, 1995 dalam Susanti, 2014).

\section{Kadar Abu}

Metode : 2 gram ekstrak dimasukkan dalam kurs yang sudah ditara dan dipijarkan perlahan-lahan. Kemudian suhu dinaikkan secara bertahap hingga $600 \pm 25^{\circ} \mathrm{C}$ sampai bebas karbon, selanjutnya didinginkan dalam deksikator, serta timbang berat abu (Tiwari dkk., 2011).

\section{Penyiapan Bakteri Uji}

\section{Sterilisasi Alat}

Alat disiapkan dan dicuci bersih. Kemudian, alat yang sudah dicuci maka dikeringkan untuk kemudian dimasukkan ke dalam autoklaf dalam suhu $121^{\circ} \mathrm{C}$ selama 15-20 menit (Tristiyanto, 2009).

\section{Peremajaan Bakteri}

\section{Pembuatan Media Agar Miring}

Sebanyak 5 gram Nutrient Agar disuspensikan dalam $250 \mathrm{~mL}$ aquadest steril, kemudian dipanaskan hingga mendidih. Dilakukan pengadukan dengan magnetic stirrer untuk memastikan media telah tersuspensi sempurna. Kemudian, disterilkan dengan autoklaf pada suhu $121^{\circ} \mathrm{C}$ selama 15 menit (Ngajow, 2013).

Media yang sudah steril, kemudian dituang dalam tabung reaksi steril sebanyak $5 \mathrm{~mL}$. Media dituang dalam kondisi hangat $\left(40^{\circ} \mathrm{C}-45^{\circ} \mathrm{C}\right)$. Tabung reaksi yang berisi media, kemudian dimiringkan dengan kemiringan sekitar $30^{\circ}-45^{\circ}$. Mulut tabung reaksi disumbat dengan kapas kemudian ditunggu sampai media memadat (Hidayat, 1999 dalam Saraswati, 2015).

\section{Proses Peremajaan Bakteri}

Pada mikroorganisme uji yang diperoleh dilakukan perbanyakan kultur murni. Kultur murni diambil menggunakan jarum ose kemudian digoreskan pada media agar miring secara aseptis. Sebelum dilakukan inkubasi, ditambahkan gaspak disekitar tabung reaksi didalam inkubator. Setelah itu dilakukan inkubasi selama \pm 48 jam pada suhu $37^{\circ} \mathrm{C}$ untuk Propionibacterium acnes. Sebelum digunakan untuk menguji potensi daya hambat dari ekstrak etanol 
daun suruhan, dilakukan pengenceran bertingkat pada kultur bakteri untuk mengendalikan populasi bakteri (Dyah Ayu, 2013).

\section{Pembuatan Suspensi Bakteri}

Sebanyak 1,3 gram Nutrient Broth disuspensikan dalam $100 \mathrm{~mL}$ aquadest steril, kemudian dipanaskan hingga mendidih. Dilakukan pengadukan dengan magnetic stirrer untuk memastikan media telah tersuspensi sempurna. Kemudian, disterilkan dengan autoklaf pada suhu $121^{\circ} \mathrm{C}$ selama 15 menit (Ngajow, 2013).

Pembuatan suspensi bakteri dilakukan dengan mengambil isolat yang merupakan koloni tunggal 1 ose kemudian dimasukkan ke dalam NB (Nutrient Broth) cair dalam erlenmeyer. Kemudian ditambahkan gaspak disekitar erlenmeyer yang berisi suspensi bakteri. Setelah itu dilakukan inkubasi selama 2x24 jam pada suhu ruang (Dyah Ayu, 2013).

\section{Pengenceran Bakteri}

Berikut ini langkah-langkah pengenceran untuk menentukan jumlah sel bakteri Propionibacterium acnes dengan metode ALT (Velhner, M dan Milanov, D., 2015)

Hasil suspensi bakteri $\left(10^{0}\right)$ sebanyak 1 $\mathrm{mL}$ dipindahkan menggunakan pipet steril ke dalam tabung reaksi berisi $9 \mathrm{~mL}$ larutan $\mathrm{NaCl}$ 0,85\% (untuk mendapatkan pengenceran $10^{-1}$ ).

Suspensi dari pengenceran $10^{-1}$ dipindahkan sebanyak $1 \mathrm{~mL}$ dengan pipet steril ke dalam tabung reaksi berisikan 9 $\mathrm{mL}$ larutan $\mathrm{NaCl} \quad 0,85 \%$ (untuk mendapatkan pengenceran $10^{-2}$ ).

Dibuat pengenceran $10^{-3}, 10^{-4}, 10^{-5}, 10^{-6}$, $10^{-7}, 10^{-8}, 10^{-9}$ dan $10^{-10}$ dengan cara yang sama seperti pada poin (2).

Tahap selanjutnya pada pengenceran $10^{-9}$ diambil sebanyak $1 \mathrm{~mL}$, kemudian dimasukkan ke dalam cawan petri yang sudah berisi media NA padat, kemudian diinkubasi dengan suhu $37^{\circ} \mathrm{C}$.

Hasil perhitungan pada pengenceran yakni pada pengenceran $10^{-9}$ terdapat 209 koloni bakteri Propionibacterium acnes sehingga koloni bakteri yang digunakan untuk pengujian adalah pengenceran $10^{-9}$ karena memenuhi syarat dimana jumlah bakteri yang harus tumbuh adalah 10-300 koloni.

Uji Antibakteri Ekstrak Etanol Daun Suruhan (Peperomia Pellucida.L)

\section{Pembuatan Media Uji}

Sebanyak 5 gram media Nutrient Agar (NA) dilarutkan dalam $250 \mathrm{~mL}$ aquadest steril. Kemudian media dipanaskan dengan hot plate stirer untuk memastikan media tersuspensi sempurna. Setelah media tersuspensi sempurna, kemudian 
dimasukkan dalam autoklaf pada suhu $121^{\circ} \mathrm{C}$ selama $15-20$ menit, lalu ditunggu sampai suhu hangat $\left(40^{\circ} \mathrm{C}-45^{\circ} \mathrm{C}\right)$. NA yang sudah siap, dituangkan kedalam cawan petri sebanyak $20 \mathrm{~mL}$. Media didiamkan sampai memadat (Ngajow, 2013).

\section{Pembuatan Konsentrasi Larutan Uji}

Sampel yang akan digunakan dalam penelitian ini dibagi menjadi kontrol positif, kontrol negatif dan sampel ekstrak. Kontrol positif diantaranya clindamycin dan kapsul komersil. Kontrol negatif diantaranya aquadest. Sedangkan sampel yang akan diuji yaitu ekstrak etanol daun suruhan yang dibagi menjadi beberapa konsentrasi diantaranya $25 \%$, $50 \%, 75 \%$ dan 100\%. Berikut jumlah masing-masing sampel yang digunakan dalam penelitian:

Tabel 1. Larutan Uji

\begin{tabular}{ccc}
\hline & Sampel & Berat (b/v) \\
\hline Kontrol Negatif & Aquadest & $8 \mathrm{ml}$ \\
Kontrol Positif & Clindamycin & $0,5 \mathrm{gr}$ \\
& Kapsul Herbal Komersil & $1 \mathrm{gr}$ \\
Ekstrak & $25 \%$ & $0,25 \mathrm{gr}$ \\
& $50 \%$ & $0,50 \mathrm{gr}$ \\
& $75 \%$ & $0,75 \mathrm{gr}$ \\
& $100 \%$ & $1 \mathrm{gr}$ \\
\hline
\end{tabular}

\section{Proses Uji Aktivitas Antibakteri}

Uji aktivitas antibakteri dilakukan dengan menggunakan metode sumur agar dengan langkah-langkah sebagai berikut (Dyah Ayu, 2013). Media yang sudah dituang ke cawan petri disiapkan. Media Nutrient Agar (NA) yang sudah dingin dan memadat selanjutnya ditanami bakteri Propionibacterium acnes yang diambil dari suspensi bakteri (Aziz, 2010 dalam
Saraswati, 2015). Kemudian dibuat 4 lubang berukuran $6 \mathrm{~mm}$ dengan menggunakan tips micro pipet. Pada masing-masing lubang sumuran dimasukkan kontrol positif, kontrol negatif, dan ekstrak yang diujikan. Inkubasikan pada suhu $37^{\circ} \mathrm{C}$ selama 24 jam. Uji dilakukan dengan dua kali pengulangan. 
Pengamatan Dan Pengukuran Zona Hambat

Pengamatan dan pengukuran diameter hambatan dilakukan setelah masa inkubasi 24 jam. Zona hambatan yang terbentuk diukur dengan menggunakan jangka sorong (Dyah Ayu, 2013) Berdasarkan zona hambat yang terbentuk maka aktivitas antibakteri dapat digolongkan menjadi beberapa golongan yaitu antibakteri yang tergolong lemah (zona hambat $<5 \mathrm{~mm}$ ), sedang (zona hambat antara 5-10 $\mathrm{mm}$ ), kuat (zona hambat antara 10-20 mm), dan tergolong sangkat kuat (zona hambat > $20 \mathrm{~mm}$ ) (Pradana, 2013).

\section{HASIL}

\section{Hasil determinasi tumbuhan suruhan} (Peperomia Pellucida L.)

Determinasi dilakukan di Pusat Penelitian Konversasi Tumbuhan Dan Kebun Raya (LIPI). Adapun hasil yang didapat dari determinasi tersebut bahwa tumbuhan suruhan merupakan jenis Peperomia pellucida (L.) Kunth, suku dari Piperaceae

Hasil organoleptis ekstrak etanol daun suruhan (Peperomia Pellucida L.) dapat dilihat sebagai berikut :

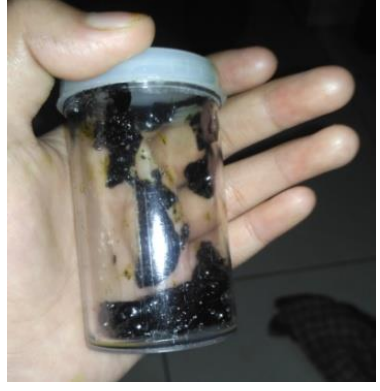

Gambar 1. Ekstrak Etanol Daun Suruhan

Tabel 2. Hasil Organoleptis Ekstrak

\begin{tabular}{cc}
\hline Parameter & Hasil \\
\hline Bentuk & Kental \\
Warna & Hjau kehitaman \\
Bau & Khas \\
Rasa & Pahit
\end{tabular}

Berdasarkan Tabel 2. hasil organoleptis ekstrak etanol daun suruhan (Peperomia pellucida L.) yaitu bentuk ekstrak yaitu kental, warna ekstrak yaitu hijau kehitaman, bau ekstrak yaitu khas, dan rasa ekstrak yaitu pahit.

Hasil skrining fitokimia ekstrak etanol daun suruhan (Peperomia pellucida L.) dapat dilihat sebagai berikut :

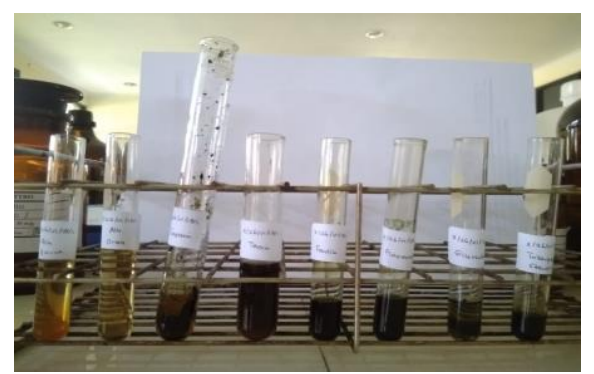

Gambar 1. Skrining Fitokimia

Tabel 3. Hasil Uji Fitokimia

\begin{tabular}{cc}
\hline Golongan & Hasil \\
Senyawa & \\
\hline Alkaloid & -
\end{tabular}




$\begin{array}{cc}\text { Saponin } & + \\ \text { Tanin } & + \\ \text { Fenolik } & + \\ \text { Flavonoid } & + \\ \text { Triterpenoid } & + \\ \text { Steroid } & + \\ \text { Glikosida } & +\end{array}$

Keterangan : $(+)$ : Menunjukkan reaksi positif

( - ) : Menunjukkan reaksi negatif

Berdasarkan Tabel 3. ekstrak etanol daun suruhan (Peperomia pellucida L.) positif mengandung saponin, tanin, fenolik, flavonoid, triterpenoid, steroid, dan glikosida.

Hasil rendemen ekstrak etanol daun suruhan (Peperomia pellucida L.) dapat dilihat pada tabel sebagai berikut :

Tabel 4. Hasil Rendemen Ekstrak

\begin{tabular}{cc}
\hline Sampel & Jumlah \\
\hline Berat Ekstrak & $25 \mathrm{gr}$ \\
Berat Simplisia & $300 \mathrm{gr}$ \\
Hasil & $8,33 \%$
\end{tabular}

Berdasarkan Tabel 4. hasil rendemen ekstrak yang didapat yaitu $8,33 \%$. 
Hasil uji kadar abu ekstrak etanol daun suruhan (Peperomia Pellucida L.) dapat dilihat pada tabel berikut :

Tabel 5. Hasil Uji Kadar Abu

\begin{tabular}{cc}
\hline Parameter & Ekstrak Etanol \\
\hline Jumlah & 2 gram \\
Kadar Abu & $17,23 \%$ \\
\hline
\end{tabular}

Berdasarkan Tabel 5. ekstrak etanol daun suruhan (Peperomia pellucida memiliki kadar abu yaitu 17,23\%.

Hasil pengamatan daya hambat ekstrak etanol daun suruhan (Peperomia pellucida L.) terhadap Propionibacterium acnes berdasarkan diameter dan zona bening sebagai berikut :
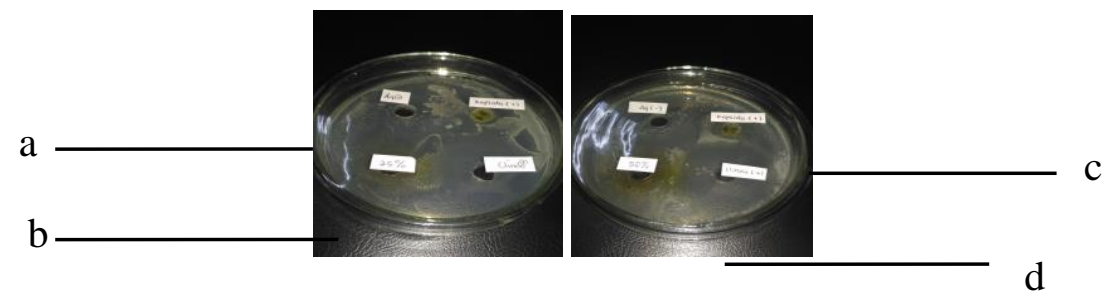

e
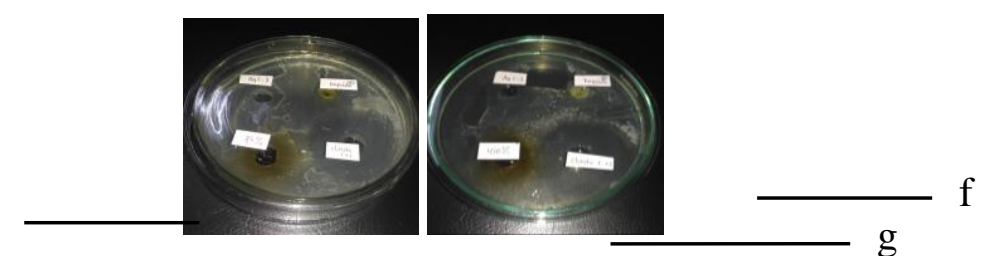

Gambar 2. Diameter Zona Bening

Keterangan : a : aquadest ; b : konsentrasi 25\% ; c : kapsul herbal komersil ; d : konsentrasi $50 \%$; e : konsentrasi $75 \%$; f : clindamycin $150 \mathrm{mg}$; g : konsentrasi $100 \%$

Tabel 6. Rata-rata Diameter Dan Luas Zona Hambat

\begin{tabular}{ccc}
\hline Sampel & $\begin{array}{c}\text { Rata-rata } \\
\text { diameter }\end{array}$ & $\begin{array}{c}\text { Rata-rata } \\
\text { luas }\end{array}$ \\
\hline Kontrol Negatif & - & - \\
(Aquadest) & & \\
Kontrol Positif & $26,74 \mathrm{~mm}$ & $813,72 \mathrm{~mm}^{2}$ \\
(Clindamycin) & & \\
Kontrol Positif & & $188,85 \mathrm{~mm}^{2}$ \\
(Kapsul herbal & $10,44 \mathrm{~mm}$ & \\
komersil) & & $101,70 \mathrm{~mm}^{2}$ \\
$25 \%$ & $6,65 \mathrm{~mm}$ & $130,98 \mathrm{~mm}^{2}$ \\
$50 \%$ & $8,2 \mathrm{~mm}$ & $299,28 \mathrm{~mm}^{2}$ \\
$75 \%$ & $13,7 \mathrm{~mm}$ & \\
\hline
\end{tabular}




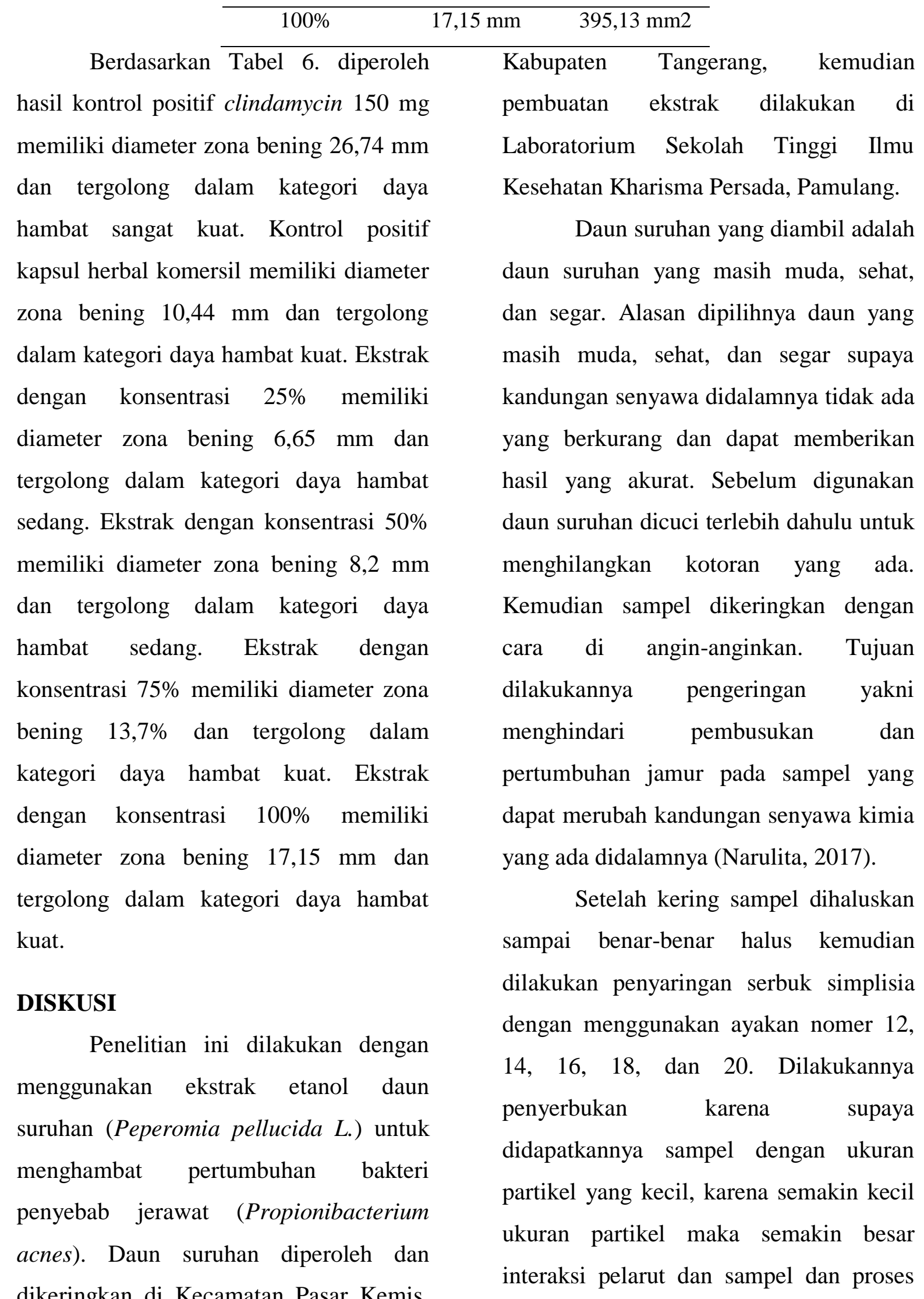

dikeringkan di Kecamatan Pasar Kemis, 
ekstraksi akan semakin efektif (Narulita, 2017).

Serbuk daun suruhan yang sudah halus kemudian ditimbang dan didapatkan 300 gram serbuk simplisia untuk selanjutnya dibuat ekstrak dengan menggunakan metode maserasi. Alasan dipilihnya metode tersebut adalah praktisnya pengerjaan dan alat yang digunakan sederhana dan mudah didapat. Metode ini paling cocok digunakan untuk senyawa yang termolabil (Saraswati, 2015).

Dalam penelitian ini pelarut yang digunakan yaitu etanol $96 \%$ dan air. Alasan digunakannya etanol $96 \%$ sebagai pelarut karena etanol merupakan pelarut yang paling maksimal menarik senyawa fenolik dan flavonoid (Mardiyaningsih, 2014).

Proses maserasi dilakukan dengan mencampurkan simplisia dengan pelarut sebanyak 1:10. Hal ini dilakukan supaya dapat terendam seluruh simplisia dengan sempurna kemudian didiamkan selama $3 \times 24$ jam. Hal ini bertujuan untuk memaksimalkan proses penarikan senyawa-senyawa kimia yang terdapat pada simplisia daun suruhan tersebut (Narulita, 2017).

Selama proses perendaman, sampel disimpan dalam wadah tertutup rapat yang bertujuan agar sampel tidak terkontaminasi. Setelah itu dilakukan penyaringan dengan menggunakan kertas saring untuk memisahkan antara filtran dan filtrat. Kemudian filtrat akan di evaporasi untuk mendapatkan ekstrak yang diinginkan.

Pengujian fitokimia pada ekstrak etanol daun suruhan dilakukan untuk mengetahui golongan metabolit sekunder yang terdapat pada ekstrak. Berdasarkan Tabel 4.2 dan Lampiran 9 hasil yang didapat dari skrining fitokimia adalah adanya senyawa saponin, tanin, fenolik, flavonoid, triterpenoid, steroid dan glikosida pada ekstrak. Hasil tersebut diperkuat dengan berbagai jurnal yang telah melakukan skrining fitokimia terhadap suruhan.

Beberapa penelitian terkait dengan tanaman suruhan adalah bahwa ekstrak etanol tanaman suruhan efektif dalam pengobatan luka bakar derajat I pada kelinci (Subagja, 2017). Ekstrak etanol tanaman suruhan memiliki efektifitas dalam penyembuhan luka bakar derajat I dikarenakan terdapat senyawa alkaloid, flavonoid, tanin, saponin, dan steroid.

Dengan demikian tanaman suruhan memiliki kandungan antibakteri yang berasal dari senyawa alkaloid. Senyawa flavonoid yang berfungsi 
sebagai antioksidan, antibakteri, dan antiinflamasi pada luka bakar. Senyawa tanin yang berfungsi sebagai antioksidan, menghentikan pendarahan dan mempercepat penyembuhan luka. Kandungan saponin berpotensi membantu penyembuhan luka, sedangkan kandungan steroid berfungsi sebagai antibiotik diantaranya sebagai antibakteri dan antijamur.

Beberapa penelitian lain terkait lainnya dengan suruhan adalah bahwa ekstrak etanol suruhan efektif dalam menghambat pertumbuhan bakteri Staphylococcus aureus secara in vitro. Tumbuhan suruhan dapat membunuh bakteri berdasarkan hasil penelitian yang ada dikarenakan terdapat senyawa flavonoid dan polifenol didalamnya (Dandirwalu dkk., 2015).

Beberapa penelitian lain terkait dengan daun suruhan adalah bahwa ekstrak etanol daun suruhan mempunyai aktivitas antibakteri terhadap bakteri Shigella dysentriae. Daun suruhan diperkirakan memiliki aktivitas antibakteri dikarenakan mengandung senyawa tannin dan flavonid (Majumder dkk., 2011).

Beberapa senyawa tersebut merupakan antimikroba atau antibakteri yang terdapat dalam daun suruhan.
Antibakteri merupakan zat yang dapat menghambat bakteri penyebab infeksi. Bakteri yang digunakan dalam penelitian ini adalah Propionibacterium acnes yang merupakan bakteri anaerob yang ikut berperan dalam pembentukan jerawat. Penyebab terjadinya jerawat yaitu perubahan sistem hormonal yang merangsang peningkatan produksi kelenjar minyak dikulit. Biasanya terjadi pada saat seseorang mengalami menstruasi, kehamilan atau stress sehingga memicu timbulnya jerawat (Narulita, 2017).

Selanjutnya dilakukannya uji kadar abu terhadap ekstrak. Berdasarkan Tabel 4.4 dan Lampiran 8 hasil uji kadar abu yang didapat yakni 17,23\% . Penentuan kadar abu dilakukan untuk memberikan gambaran kandungan mineral internal dan eksternal.

Berdasarkan buku monografi ekstrak tumbuhan obat kadar abu total tidak boleh lebih dari 16,6\%. Dengan demikian hasil tersebut melebihi parameter kadar abu ekstrak. Hal tersebut dapat terjadi karena kemungkinan masih adanya bahan pengotor atau kontaminan yang terkandung dalam ekstrak.

Uji daya hambat terhadap bakteri bertujuan untuk mengetahui kemampuan dari ekstrak etanol daun suruhan untuk 135 
menghambat pertumbuhan bakteri yang diujikan yakni Propionibacterium acnes. Dalam penelitian ini, menggunakan metode sumur agar dengan demikian dapat dilihat zona bening di sekitar lubang sumur. Alasan dipilihnya metode sumuran yaitu dengan menggunakan metode sumuran dapat menghasilkan diameter zona hambat yang besar serta pada metode sumuran terjadi proses osmolaritas dari konsentrasi ekstrak yang lebih tinggi dari metode difusi cakram. Pada metode sumuran, setiap lubang diisi dengan konsentrasi ekstrak maka osmolaritas terjadi lebih menyeluruh dan lebih homogen serta konsentrasi ekstrak yang dihasilkan lebih tinggi dan lebih kuat untuk menghambat pertumbuhan bakteri (Prayoga, 2013).

Zona bening ini menunjukan adanya kemampuan ekstrak dalam menghambat pertumbuhan bakteri. Sebelum melakukan uji antibakteri ini alat dan bahan yang akan digunakan harus disterilkan terlebih dahulu dengan tujuan supaya alat dan bahan yang digunakan tidak terkontaminasi dengan mikroorganisme lain. Bakteri Propionibacterium acnes yang digunakan, sebelumnya dilakukan peremajaan terlebih dahulu untuk meregenerasi bakteri agar diperoleh bakteri yang muda dan tidak terkontaminasi.

Bakteri Propionibacterium acnes bersifat anaerob obligat sehingga pada saat peremajaan dan pengujian untuk menumbuhkan bakteri tersebut perlu adanya penambahan gaspak (AnaeroGen $^{\mathrm{TM}}$ Compact). Hal ini bertujuan supaya tidak adanya oksigen sehingga bakteri yang digunakan dalam penelitian dapat tumbuh dan dapat digunakan pengujian selanjutnya. Clindamycin digunakan sebagai kontrol positif karena clindamycin utamanya digunakan dalam pengobatan infeksi yang disebabkan oleh bakteri anaerob. Pada penelitian ini digunakan clindamycin 150 mg. Sedangkan kontrol positif lainnya yang digunakan yakni kapsul herbal komersil. Kontrol negatif yang digunakan yaitu aquadest.

Pada pengamatan setelah inkubasi selama 24 jam didapatkan hasil pada Tabel 4.5 diperoleh bahwa ekstrak dengan konsentrasi $25 \%$ yaitu rata-rata diameter $6,65 \mathrm{~mm}$ dan rata-rata luas $101,70 \mathrm{~mm}^{2}$. Hasil dari ekstrak dengan konsentrasi $50 \%$ yaitu rata-rata diameter $8,2 \mathrm{~mm}$ dan rata-rata luas $130,98 \mathrm{~mm}^{2}$. Hasil dari ekstrak dengan konsentrasi $75 \%$ yaitu rata-rata diameter $13,7 \mathrm{~mm}$ dan rata-rata luas 299,28 $\mathrm{mm}^{2}$. Hasil dari ekstrak 136 
dengan konsentrasi $100 \%$ yaitu rata-rata diameter $17,15 \mathrm{~mm}$ dan rata-rata luas $395,13 \mathrm{~mm}^{2}$.

Jika dibandingkan dengan clindamycin sebagai kontrol positif dalam penelitian ini maka kemampuan ekstrak etanol daun suruhan lebih rendah namun jika dibandingkan dengan kontrol positif kapsul herbal komersil, ekstrak etanol daun suruhan konsentrasi $75 \%$ dan $100 \%$ memiliki daya hambat yang lebih besar.

Berdasarkan parameter zona hambat yang dilihat dari kemampuan daya hambat berupa diameter zona bening maka diperoleh bahwa ekstrak etanol daun suruhan dengan konsentrasi $25 \%$ dan $50 \%$ memiliki daya hambat yang sedang. Ekstrak etanol daun suruhan dengan konsentrasi $75 \%$ dan $100 \%$ memiliki daya hambat yang kuat.

Hasil penelitian diperkuat dengan penelitian terkait mengenai Uji Daya Hambat Ekstrak Etanol Suruhan (Piperomia pellucida L.) Terhadap Pertumbuhan Bakteri Staphylococcus aureus Secara In-Vitro mendapat hasil bahwa pada konsentrasi $25 \%$ tidak memberikan respon hambat, konsentrasi 50\% memiliki respon hambat lemah, dan konsentrasi $75 \%$ memiliki daya hambat sedang (Dandirwalu dkk., 2015).
Dengan demikian hasil yang diperoleh dipengaruhi oleh konsentrasi ekstrak yang diujikan. Semakin tinggi konsentrasi ekstrak maka semakin besar pula daya hambat ekstrak dalam menghambat pertumbuhan bakteri. Banyak faktor yang mempengaruhi keberhasilan dalam uji antibakteri ini seperti konsentrasi ekstrak, waktu inkubasi, pemilihan pelarut dalam pembuatan ekstrak dan keadaan ruangan uji.

Pengerjaan dilakukan didalam Laminar Air Flow (LAF). Seharusnya di sterilkan dengan menggunakan sinar UV, dikarenakan keterbatasan alat dengan demikian menggunakan 2 bunsen yang di letakkan pada kanan dan kiri untuk menjaga kestabilan lingkungan agar tetap steril.

\section{SIMPULAN}

Standarisasi ekstrak etanol daun suruhan (Peperomia pellucida L.) secara organoleptis bentuk ekstrak adalah ekstrak kental, berwarna hijau kehitaman, rasa pahit dan bau khas. Kadar abu di dapat sebesar 17,23\%. Pada skrining fitokimia dari ekstrak menunjukkan adanya senyawa saponin, tanin, fenolik, 
flavonoid, triterpenoid, steroid dan glikosida.

Ekstrak etanol daun suruhan (Peperomia pellucida L.) memiliki kemampuan hambat terhadap bakteri penyebab jerawat (Propionibacterium acnes). Ekstrak dengan konsentrasi 25\% $(6,65 \mathrm{~mm})$ dan konsentrasi $50 \%(8,2 \mathrm{~mm})$ memiliki daya hambat sedang. Ekstrak dengan konsentrasi $75 \%(13,7 \mathrm{~mm})$ dan konsentrasi $100 \%(17,15 \mathrm{~mm})$ memiliki daya hambat kuat.

\section{DAFTAR PUSTAKA}

Afriyanti, R. N. 2015, 'Acne Vulgaris Pada Remaja'. [Jurnal Majority], vol. 4, no. 6, hh. 102-109.

Dandirwalu, E., Watuguly, T.W. 2015, 'Uji Daya Hambat Ekstrak Etanol Suruhan (Piperumia pellucida L.H.B Kunth) Terhadap Pertumbuhan Bakteri Staphylococcus aureus Secara In Vitro'. [Jurnal Biologi, Pendidikan dan Terapan]. Vol. 2. No. 1.

Dyah, A. 2013, 'Uji Efektivitas Sabun Cair dari Ekstrak Daun Pepaya (Carica Papaya L.) Terhadap Staphylococcus aureus'. [Skripsi], Makasar : Fakultas
Farmasi Universitas Indonesia Timur Makasar.

Febriyati. 2010, 'Analisis Komp onen Kimia Fraksi Minyak Atsiri Daun Sirih (Piper bettle Linn) dan Uji Aktivitas Antibakteri terhadap Beberapa Jenis Bakteri Gram Positif'. [Skripsi], Jakarta : Fakultas Farmasi Universitas Islam Negeri Syarif Hidayatullah.

Khan, Z.Z.., Assi M., Moore, T.A. 2009, 'Recurent Epidural Abcess Caused by Propionibacterium acnes'. [Khansas Journal of Medicine], hh. 92-95.

Majumder, P., Kumar, K.V., Arun. 2011, 'Establishment of Quality Parameters and Pharmacognostic Evaluation of Leaves of Peperomia pellucida (L.)'. [Hbk. International Journal of Pharmacy and Pharmaceutical Sciences].

Movita, T. 2013, 'Acne Vulgaris', [Continuing Medical

Education]. IDI. CDK 203/vol. 40 no. 4 , hh. 40.

Narulita, W. 2017, 'Uji Efektivitas Ekstrak Daun Binahong (Anredera Cordifolia) 
Dalam Menghambat

Pertumbuhan Bakteri

Propionibacterium Acnes

Secara In Vitro'. [Skripsi],

Lampung : Fakultas Tarbiyah

Dan Keguruan Universitas

Islam Negeri Raden Intan

Lampung

Ngajow, M., Abidjulu, J. and K. V. S. 2013, 'Pengaruh Antibakteri Ekstrak Kulit Batang Matoa (Pometia pinnata) Terhadap Bakteri Staphylococcus aureus secara In Vitro. [Jurnal MIPA Unsrat Online]. Vol. 2. No. 2. hh. 128-132.

Pradana., Dedi. 2013, 'Uji Daya Hambat Ekstrak Kulit Batang Rhizophora mucronata Terhadap Pertumbuhan Bakteri Aeromonas hydrophila, Streptococcus agalactiae Dan Jamur Saprolegnia sp. Secara In Vitro’. Medan : Departemen Biologi, Fakultas MIPA Universitas Sumatera Utara.

Saraswati, F.N. 2015, 'Uji Aktivitas Antibakteri Ekstrak Etanol 96\% Limbah Kulit Pisang Kepok Kuning (Musa balbisiana) Terhadap Bakteri Penyebab Jerawat (Staphylococcus epidermidis, Staphylococcus aureus, dan Propionibacterium acne)'. [Skripsi] Jakarta : Fakultas Farmasi Universitas Islam Negeri Jakarta.

Subagja, S. 2017, 'Uji Ektefitivitas Sediaan Salep Ekstrak Etanol Tanaman Suruhan (Peperomia pellucida) Sebagai Pengobatan Luka Bakar Derajat I Pada Kulit Kelinci (Oryctolagus cuniculus)'. [Prosiding Seminar Nasional Tahunan Matematika, Sains, dan Teknologi].

Tiwari., P. Kumar., B. Kaur., M. Kaur., G. Kaur. 2011, 'Phytochemical screening and Extraction: A Review'. [Internationale Pharmaceutical Sciencia]. Vol. 1. Issue. 1.

Tristiyanto. 2009, 'Studi Aktivitas Antibakteri dan Identifikasi Golongan Senyawa Eksrak Aktif Antibakteri Buah Gambas (Luffa acutangula roxb.). [Skripsi]. Surakarta Universitas Sebelas Maret.

United States Departement of Agriculture (USDA). 2011, 'The Plants Database'. USA ; National Plant Data Team. 
Velhner, M., \& Milanov, D. 2015, 'Resistance to Tetracycline in Escherichia coli and Staphylococcus aureus'. [Brief
Overview on Mechanism of Resistance and Epidemioogy, Arhiv Veterinarske Medicine]. Vol. 8. hh. 27-36. 